\title{
Depresjon eller demens av Alzheimers type?
}

\begin{abstract}
BAKGRUNN Forekomsten av depresjon og demens av Alzheimers type hos eldre vil øke. Symptomene kan likne, og det kan være klinisk vanskelig å skille diagnostisk mellom de to sykdomstilstandene. Dessuten kan begge tilstander forekomme samtidig. I denne artikkelen gis en oversikt over symptomer og funn som kan ha betydning for å skille depresjon fra demens av Alzheimers type.
\end{abstract}

KUNNSKAPSGRUNNLAG Artikkelen er bygd på et strukturert søk i PubMed. Det er gjort et skjønnsmessig utvalg av studier ut fra forfatternes kliniske erfaring.

RESULTATER Depresjon og demens av Alzheimers type hos eldre kan ha en rekke felles kognitive og affektive symptomer, som nedsatt hukommelse, redusert oppmerksomhet, svekkede følelsesmessige reaksjoner og initiativløshet. Kartlegging av sykdomsforløp og funksjon i dagliglivet, komparentopplysninger, nevropsykologiske tester, biomarkører og bildediagnostikk av hjernen kan være til hjelp i den differensialdiagnostiske vurderingen.

FORTOLKNING Depresjon og demens av Alzheimers type hos eldre kan kartlegges av fastlegen. Kartleggingen bør inneholde vurdering av sykdomsforløp, funksjon i dagliglivet, innhenting av komparentopplysninger og kognitiv screening. Dersom fastlegens utredning ikke gir entydige svar eller det dreier seg om en ung pasient, bør det henvises til spesialisthelsetjenesten.

Antallet eldre i befolkningen øker (1), og aldring er en sentral risikofaktor for å utvikle demens av Alzheimers type (2). Det er forventet at forekomsten av sykdommen vil bli fordoblet de neste 20 år.

For eldre kan en depresjon medføre nedsatt hukommelse og redusert oppmerksomhet (3) samt svikt i eksekutive funksjoner, dvs. evnen til å planlegge, regulere og iverksette sammensatte kognitive operasjoner (4). Hos eldre med depresjon kan kognitiv svikt være fremtredende (5), tidvis slik at pasienten oppleves å ha en demenssykdom, kalt «depresjon med demensliknende atferd». Svekkede følelsesmessige reaksjoner, tap av interesse og initiativløshet er andre symptomer på depresjon som overlapper med symptomer på demens av Alzheimers type $(6,7)$.

En systematisk gjennomgang av internasjonale studier viser at om lag $19 \%$ av hjemmeboende eldre har en depresjon, mens forekomsten er dobbelt så høy hos eldre som bor på institusjon (8). Hensikten med denne artikkelen er presentere forskjeller mellom depresjon og demens av Alzheimers type.

\section{Kunnskapsgrunnlag}

Artikkelen bygger på søk i PubMed og forfatternes egen kliniske erfaring. Lærebøker i nevropsykologi, alderspsykiatri og demens ble tatt med der de gir viktig tilleggsinformasjon. Det ble søkt etter engelskspråklige originalartikler, oversiktsartikler og metaanalyser som spesifikt omhandlet differensialdiagnostikk ved depresjon og demens av Alzheimers type, publisert i perioden 1995-2012.

Søkekombinasjonene «Alzheimers differentiation depression» resulterte i 55 treff, mens kombinasjonene "Alzheimers distinguish depression» ga 56 treff og «Alzheimers differentiate depression» ga 71 treff totalt 182 treff.

Av disse ble 33 artikler vurdert som aktuelle ut fra overskrift og/eller sammendrag. 16 av disse ble ekskludert på grunn av manglende relevans (problemstillingen var utenfor tema i vår artikkel) eller de var skrevet på et annet språk enn engelsk. Det endelige antallet artikler som ble tatt med var 17. Figur 1 gir en oversikt over søkestrengen.

\section{Demens av Alzheimers type og depresjon}

Alzheimers sykdom er en degenerativ hjerneorganisk lidelse som kjennetegnes av blant annet progredierende svikt i hukommelsesfunksjoner, språkfunksjon, visuospatiale evner, eksekutive funksjoner og orienteringsevne $(3,9,10)$. Alzheimers sykdom er den vanligste årsaken til demens og ligger bak mer enn $60 \%$ av alle tilfeller (9).

Grunnsymptomene ved depresjon er labilt stemningsleie, interesse- og gledesløshet og tap av energi. Øvrige depressive symptomer er redusert selvfølelse, selvbebreidelse, angst, apati, nedstemt tankemønster, søvnvansker, selvmordstanker, svekket oppmerksomhet og initiativløshet. For å kunne stille en depresjonsdiagnose må to av grunnsymptomene samt to av de øvrige depressive symptomene ha vedvart i mer en to uker (11).

Hos eldre kan det være flere årsaker til depresjon - bildet er ofte sammensatt. Både tapsopplevelser, ensomhet og somatiske sykdommer kan gjøre eldre sårbare for depressive plager (12).

\author{
Martin Bystad \\ martin.k.bystad@uit.no \\ Alderspsykiatrisk avdeling \\ Universitetssykehuset Nord-Norge \\ og \\ Institutt for psykologi \\ Universitetet i Tromsø

\section{Karin Pettersen} \\ Ole Kristian Grønli \\ Alderspsykiatrisk avdeling \\ Universitetssykehuset Nord-Norge \\ Se også kunnskapsprøve \\ på www.tidsskriftet.no/quiz
}

\section{HOVEDBUDSKAP}

Depresjon og demens av Alzheimers type kan ha overlappende symptomer og være vanskelig å skille fra hverandre

Sykdomsutvikling, komparentopplysninger, daglig fungering og kognitive tester vil være til hjelp for å skille tilstandene

I enkelte tilfeller, spesielt hos yngre pasienter, er det behov for utredning i spesialisthelsetjenesten 
Søk i PubMed $=182$ treff totalt

Grovsortering av aktuelle artikler

ut fra overskrift og sammendrag

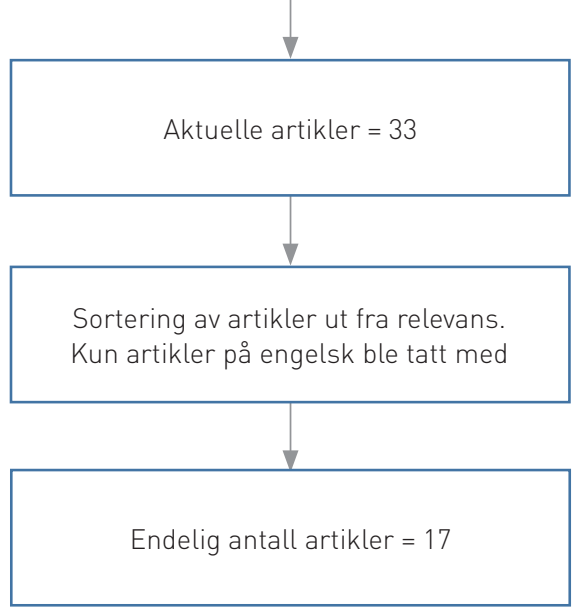

Figur 1 Oversikt over søkestrengen

Sammenhengen mellom depresjon og demens av Alzheimers type er kompleks. Undersøkelser viser at opptil $50 \%$ av alle med demens av Alzheimers type får depressive plager (13). Dette kan imidlertid variere. Det er mulig andelen er høyere, siden depressive symptomer er vanskeligere å observere hos pasienter med langtkommet demens (14). Sviktende kognitiv kapasitet og redusert språkfunksjon kan gjøre det vanskelig å kommunisere og uttrykke depressive symptomer.

Ved demens av Alzheimers type er det imidlertid ikke vanlig at pasienten viser tegn på alvorlig depresjon (7). Både tap av mestring og hjerneorganiske faktorer kan øke risikoen for depressive plager (15). Det er økt risiko for å utvikle demens av Alzheimers type der det har vært tilbakevendende depresjoner tidligere i livet (16). Det er også vist at depressive symptomer kan være debutsymptomer på demens av Alzheimers type $(13,17)$.

\section{Differensialdiagnostikk}

Det finnes ingen enkeltstående biologisk eller psykologisk test som kan skille demens av Alzheimers type fra depresjon. Her presenteres noen forskningsmessige funn som kan være til hjelp i den differensialdiagnostiske vurderingen (tab 1).

En somatisk legeundersøkelse med relevante blodprøver er viktig for å utelukke andre årsaker til de aktuelle symptomene. Blodprøver som bør tas er Hb, SR, FT4, kreatinin, vitamin $B_{12}$, homocystein, folinsyre, elektrolytter, albumin, TSH og glukose.

\section{Debut og forløp}

Det er viktig å undersøke tidsforløpet mellom den kognitive svikten og de depressive symptomene. En depresjon oppstår ofte subakutt, dvs. over uker og måneder, mens demens av Alzheimers type utvikles langsomt over flere år $(8,18,19)$. Komparentopplysninger og sykdomshistorie er derfor svært viktig.

Debuttidspunkt for symptomene og endringer i kognitiv kapasitet over tid bør kartlegges grundig. Det finnes egne standardiserte anamneseskjemaer på norsk som fylles ut av pårørende og som kan være nyttige her. Spørreskjema til pårørende er ett eksempel (20).

\section{Problemer med daglige gjøremål}

Ved demens av Alzheimers type ses ofte problemer med å bruke kjente husholdningsapparater, håndtere økonomien, bruke

Tabell 1 Symptomer og funn som kan være til hjelp for å skille depresjon fra demens av Alzheimers type. Basert på studiene som er omtalt i denne artikkelen

\begin{tabular}{lll}
\hline Symptom/funn & Demens av Alzheimers type & Depresjon \\
Sykdomsforløp & Meget langsomt & Subakutt \\
Redusert intellektuelt evnenivå & Vanlig & Ikke vanlig \\
Svekket tidsorientering & Vanlig & Ikke vanlig \\
$\begin{array}{l}\text { Subjektiv opplevelse av hukom- } \\
\text { melsesproblemer }\end{array}$ & Benektende, skjuler sym- & Ofte overdreven opplevelse \\
Benevningsvansker & Vanlig & av egen hukommelsessvikt \\
Svekket ADL-funksjon & Vanlig & Ikke vanlig \\
Utslag på biomarkører & Vanlig & Ikke vanlig \\
Medial temporal atrofi & Vanlig & Ikke vanlig \\
\hline
\end{tabular}

telefonen, planlegge innkjøp, lage mat og bilkjøring. En slik svikt i håndtering av daglige gjøremål (ADL, Activity of Daily Life) er vanlig ved demens av Alzheimer type, men uvanlig ved depresjon $(21,22)$.

Ved uttalt depresjon kan imidlertid tilbøyeligheten til å ta initiativ, men ikke selve evnen til å håndtere daglige gjøremål være alvorlig redusert. Dersom en pasient gradvis får større problemer med å utføre sine daglige gjøremål selvstendig, trekker dette i retning av demens av Alzheimers type.

\section{Tidsorientering}

Pasienter med depresjon viser sjelden tegn til alvorlig svikt når det gjelder tidsorientering. Sammenliknet med pasienter med demens av Alzheimers type gjør de det signifikant bedre på spørsmål angående måned, årstall og årstid (21).

Pasienter med demens av Alzheimers type har som regel tidlig slike problemer (22). En undersøkelse av pasientens evne til tidsorientering vil derfor være verdifull, selv om svikt ikke alltid fanges opp tidlig i forløpet.

\section{Subjektiv oppfatning av kognitiv svikt}

Pasienter med depresjon besvarer ofte oppgaver med «jeg vet ikke», «jeg kan ikke», «jeg klarer det ikke» (18). De har en tendens til å undervurdere hukommelsen sin og å rapportere større hukommelsesvansker enn det som måles objektivt på tester og observeres i det daglige.

Derimot forsøker mange pasienter med demens av Alzheimers type å skjule/benekte hukommelsessvikt, og i opptil $80 \%$ av tilfellene er det nedsatt sykdomsinnsikt (22). Det er essensielt å vurdere pasientens subjektive oppfatning av sin hukommelsesfunksjon.

\section{MMSE og klokketest}

Screeningtester som Mini Mental Status Examination (MMSE) og klokketesten er kartleggingsverktøy som gir et grovt mål på kognitiv funksjon. Det er vist at depressive plager kan påvirke skåren på både MMSevaluering $(23,24)$ og klokketesten $(25,26)$.

I en nyere studie undersøkte Milian og medarbeidere spesifisiteten ved MMSE og klokketesten (27) når deprimerte pasienter ble vurdert mot pasienter med demens. De fant at MMSE (ved skårer under 24/30) har en spesifisitet på $92 \%$, mens klokketesten har en spesifisitet på 83 \% (for skårer under 3).

Lave skårer på MMSE og/eller klokketesten bør alltid følges opp, og videre undersøkelser er nødvendig for å kartlegge årsaken til svikten. Det er verdt å merke seg at en lavere MMSE-skår (24) enn det ADL-funksjonen tilsier, indikerer depresjon fremfor demens av Alzheimers type (28). Erfaring fra egen klinisk praksis viser også at pasienter med depresjon lettere gir opp eller svarer 
«vet ikke» ved utførelse av MMSE enn pasienter med demens av Alzheimers type.

\section{Nevropsykologiske tester}

De fleste med demens av Alzheimers type får tidlig i forløpet redusert skår på tester som måler hukommelse, tempo, oppmerksomhet, visuokonstruktiv evne og eksekutive funksjoner (3, 9). En metaanalyse av Christensen og medarbeidere viste at mange pasienter med depresjon har svekket problemløsningsevne og hukommelse og lavere tempo (29). Pasienter med alvorlig depresjon kan skåre like svakt på gjenkalling (å huske en liste med ord etter 30 minutter) som pasienter med demens av Alzheimers type (30). Det har imidlertid vist seg at de med depresjon skårer signifikant bedre enn de med demens av Alzheimers type på tester som måler gjenkjenning og gjenkalling ved hjelp av stikkord (31, 32).

Studier indikerer at tester som setter krav til læring (33), benevning og kompleks visuokonstruktiv evne kan skille depresjon fra demens av Alzheimers type (29, 34). Det har videre vært funnet at pasienter med demens av Alzheimers type gjør det signifikant svakere enn deprimerte ved intellektuell evnetesting (målt ved matriseresonnering, en test som måler evnen til logisk resonnering, abstrakt tenking og problemløsningsevne) (29, 35, 36). Demens av Alzheimers type medfører altså en reduksjon i intellektuelt evnenivå over få år, i motsetning til det som skjer ved en depresjon (14).

Hos eldre kan tilstandsavhengige faktorer som lav motivasjon, situasjonsbestemt angst eller forvirring føre til at de underpresterer på nevropsykologiske tester. Derfor er det viktig å skape en trygg testsituasjon og informere om hva man skal gå gjennom. Nevropsykologiske tester kan være et nyttig ledd i den differensialdiagnostiske vurderingen (21) og indikere grad av kognitiv svikt, men slik informasjon må alltid sammenstilles med andre opplysninger og utgjør aldri et selvstendig differensialdiagnostisk grunnlag.

\section{Biomarkører}

Demens av Alzheimers type innebærer en opphopning av amyloide plakk og tauprotein i hjernen (3). Derfor kan spinalpunksjon med analyse av markører for demens være verdifullt. Lav konsentrasjon av betaamyloid og høy konsentrasjon av tauproteiner (totalt og fosforylert) i spinalvæsken peker i retning av demens av Alzheimers type (3). Det foreligger funn som viser at dette kan være et av flere hjelpemidler for å skille mellom demens av Alzheimers type og depresjon $(37,38)$.

Buerger og medarbeidere viste at mengden tauprotein i spinalvæsken kan skille mellom alvorlige former for depresjon og demens av Alzheimers type i $78 \%$ av tilfellene (38). Det er imidlertid rapportert om pasienter som har biomarkører i normalområdet, men som likevel har symptomer og en sykdomsutvikling som er klart forenlig med demens av Alzheimers type (39). Biomarkører kan være et differensialdiagostisk hjelpemiddel for å skille mellom demens av Alzheimers type og depresjon, men metoden har flere begrensninger.

\section{Bildediagnostikk av hjernen}

Det har vist seg at volumetri av medial temporal cortex ved hjelp av både MR- og CTundersøkelse har en nytteverdi for å differensiere mellom demens av Alzheimers type og depresjon $(40,41)$. Ved demens av Alzheimers type er atrofi av medial temporal cortex et funn som kan observeres. En kompliserende faktor er at normal aldring også gir tap av kortikal substans (9). Det bør også nevnes at medial temporal atrofi har vært observert hos pasienter med depresjon (42).

Atrofi av medial temporal cortex er likevel et funn som kan være av betydning dersom det ses i sammenheng med andre kliniske opplysninger. Graden av atrofi av temporal cortex kan gi indikasjoner på om det foreligger depresjon eller demens av Alzheimers type. Betydelig atrofi av medial temporal cortex trekker i retning av demens av Alzheimers type (40). Bildediagnostikk er uansett viktig for å kunne utelukke andre årsaker til den kognitive svikten, som for eksempel tumorer, cerebrovaskulære hendelser eller hydrocephalus (43).

\section{Konklusjon}

Det er mulig å skille depresjon og demens av Alzheimer type, men det kan i noen tilfeller være vanskelig og en oppgave som krever flere typer undersøkelser.

Pasienter med depresjon og kognitiv svikt skal følges opp over tid for å vurdere forløpet. Kunnskap om demens av Alzheimers type og depresjon er viktig for å kunne gi optimal behandling.

Vi takker førsteamanuensis og spesialist i nevropsykologi Per M. Aslaksen for innspill og kommentarer.

\section{Martin Bystad (f. 1982)}

er psykolog og ph.d.-stipendiat og under spesialisering i klinisk aldringspsykologi. Han har bidratt med idé, utforming, søk og gjennomlesing av artikler, skrev førsteutkastet og har bidratt med tolking av data.

Forfatter har fylt ut ICMJE-skjemaet og oppgir ingen interessekonflikter.

\section{Karin Pettersen (f. 1984)}

er psykolog. Hun har bidratt med skriving av avsnittene om nevropsykologiske tester, gjort rettelser, hjulpet til med å korte ned overflødig tekst, gått gjennom referansene og skrevet sammendraget.

Forfatter har fylt ut ICMJE-skjemaet og oppgir ingen interessekonflikter.

\section{Ole K. Grønli (f. 1963)}

er spesialist i psykiatri og overlege. Han har spesialkompetanse innen alderspsykiatri og er i gang med en ph.d.-grad ved Universitetet i Troms $\varnothing$. Han har bidratt med skriving, litteratursøk, gjennomlesinger av manuskriptet samt veiledet førsteforfatter

Forfatter har fylt ut ICMJE-skjemaet og oppgir ingen interessekonflikter.

\section{Litteratur}

1. Befolkningsframskrivningen 2009. Oslo: Statistisk sentralbyrå, 2009.

2. Rosenvinge $\mathrm{BH}$, Rosenvinge JH. Forekomst av depresjon hos eldre - systematisk oversikt over 55 prevalensstudier fra 1990-2001. Tidsskr Nor Lægeforen 2003; 123: 928-9.

3. Mayeux R. Clinical practice. Early Alzheimer's disease. N Engl J Med 2010; 362: 2194-201

4. Hermann LL, Goodwin GM, Ebmeier KP. The cognitive neuropsychology of depression in the elderly. Psychol Med 2007; 37: 1693-702.

5. Elderkin-Thompson V, Mintz J, Haroon E et al. Executive dysfunction and memory in older patients with major and minor depression. Arch Clin Neuropsychol 2006; 21: 669-76.

6. Thomas AJ, Gallagher P, Robinson LJ et al. A comparison of neurocognitive impairment in younger and older adults with major depression. Psychol Med 2009; 39: 725-33

7. Olin JT, Schneider LS, Katz IR et al. Provisional diagnostic criteria for depression of Alzheimer disease. Am J Geriatr Psychiatry 2002; 10: 125-8.

8. Thorpe L. Depression vs. dementia: how do we assess? The Canadian Review of Alzheimer's Disease and other Dementias 2009: 9: 17-21.

9. Hestad K, Reinvang I. Normal og patologisk kognitiv aldring - kan de skilles? Tidsskrift for Norsk Psykologforening 2008; 45: 1133-42.

10. Bäckman L, Jones S, Berger AK et al. Cognitive impairment in preclinical Alzheimer's disease: a meta-analysis. Neuropsychology 2005; 19: 520-31.

11. ICD-10. Psykiske lidelser og atferdsforstyrrelser. Genève: World Health Organization, 1993: 116-24.

12. Unützer J. Clinical practice. Late-life depression. N Engl J Med 2007; 357: 2269-76.

13. Lyketsos CG, Olin J. Depression in Alzheimer's disease: overview and treatment. Biol Psychiatry 2002: 52: 243-52.

14. Engedal K. Alderspsykiatri i praksis. Tønsberg: Forlaget Aldring og Helse, 2008: 109-118.

15. Alexopoulos GS. Depression in the elderly. Lancet 2005; 365: 1961-70

16. Saczynski JS, Beiser A, Seshadri S et al. Depressive symptoms and risk of dementia: the Framingham Heart Study. Neurology 2010; 75: 35-41.

17. Alexopoulos GS, Buckwalter K, Olin J et al. Comorbidity of late life depression: an opportunity for research on mechanisms and treatment. Biol Psychiatry 2002; 52: 543-58.

18. Karantzoulis S, Galvin JE. Distinguishing Alzheimer's disease from other major forms of dementia. Expert Rev Neurother 2011; 11: 1579-91.

19. Engedal KH, Haugen PK. Demens - fakta og utfordringer. Tønsberg: Forlaget Aldring og Helse, 2009: 176-179. 
20. Jorm AF. The Informant Questionnaire on cognitive decline in the elderly (IQCODE): a review. Int Psychogeriatr 2004; 16: 275-93.

21. Howieson DB, Loring DW, Hannay HJ. Neurobehavioral variables and diagnostic issues. I: Lezak MD. Howieson DB, Tranel D et al, red. Neuropsychological assessment. Oxford: Oxford University Press, 2004.

22. Wright SL, Persad C. Distinguishing between depression and dementia in older persons: neuropsychological and neuropathological correlates. J Geriatr Psychiatry Neurol 2007; 20: 189-98.

23. Dotson VM, Resnick SM, Zonderman AB. Differential association of concurrent, baseline, and average depressive symptoms with cognitive decline in older adults. Am J Geriatr Psychiatry 2008; 16: $318-30$

24. Folstein MF, Folstein SE, McHugh PR. «Minimental state». A practical method for grading the cognitive state of patients for the clinician. J Psychiatr Res 1975; 12: 189-98.

25. Woo BK, Rice VA, Legendre SA et al. The clock drawing test as a measure of executive dysfunction in elderly depressed patients. J Geriatr Psychiatry Neurol 2004: 17: 190-4

26. Samton JB, Ferrando SJ, Sanelli P et al. The clock drawing test: diagnostic, functional, and neuroimaging correlates in older medically ill adults. J Neuropsychiatry Clin Neurosci 2005; 17: 533-40.

27. Milian ML, Leiherr AM, Straten $G$ et al. The MiniCog, Clock Drawing Test, and the Mini-Mental State Examination in a German memory clinic: specificity of separation dementia from depression. Int Psychogeriatr 2013; 25: 96-104.

28. Vertesi A, Lever JA, Molloy DW et al. Standardized Mini-Mental State examination. Use and interpretation. Can Fam Physician 2001; 47: 2018-23.
29. Christensen H, Griffiths K, Mackinnon A et al. A quantitative review of cognitive deficits in depression and Alzheimer-type dementia. J Int Neuropsychol Soc 1997; 3: 631-51.

30. O'Carroll RE, Conway S, Ryman A et al. Performance on the delayed word recall test (DWR) fails to differentiate clearly between depression and Alzheimer's disease in the elderly. Psychol Med 1997; 27: 967-71.

31. Dierckx E, Engelborghs S, De Raedt R et al. Differentiation between mild cognitive impairment Alzheimer's disease and depression by means of cued recall. Psychol Med 2007; 37: 747-55.

32. Dierckx E, Engelborghs S, De Raedt R et al. The 10 -word learning task in the differential diagnosis of early Alzheimer's disease and elderly depression: A cross-sectional pilot study. Aging Ment Health 2011; 15: 113-21

33. Foldi NS, Brickman AM, Schaefer LA et al. Distinct serial position profiles and neuropsychological measures differentiate late life depression from normal aging and Alzheimer's disease. Psychiatry Res 2003; 120: $71-84$

34. Crowe SF, Hoogenraad K. Differentiation of dementia of the Alzheimer's type from depression with cognitive impairment on the basis of a cortical versus subcortical pattern of cognitive deficit. Arch Clin Neuropsychol 2000; 15: 9-19.

35. Mazur-Mosiewicz A, Trammell BA, Noggle CA et al. Differential diagnosis of depression and Alzheimer's disease using the Cattell-Horn-Carroll theory. Appl Neuropsychol 2011; 18: 252-62.

36. Dierckx E, Engelborghs S, De Raedt R et al. Differentiation between dementia and depression among older persons: can the difference between actual and premorbid intelligence be useful? J Geriatr Psychiatry Neurol 2008; 21: 242-9.
37. Reis T, Brandão CO, Freire Coutinho ES et al. Cerebrospinal fluid biomarkers in Alzheimer's disease and geriatric depression: preliminary findings from Brazil. CNS Neurosci Ther 2012; 18: $524-9$.

38. Buerger K, Zinkowski R, Teipel SJ et al. Differentiation of geriatric major depression from Alzheimer's disease with CSF tau protein phosphorylated at threonine 231. Am J Psychiatry 2003; 160: 376-9.

39. Oksengard AR, Cavallin L, Axelsson R et al. Lack of accuracy for the proposed 'Dubois criteria' in Alzheimer's disease: a validation study from the Swedish brain power initiative. Dement Geriatr Cogn Disord 2010; 30: 374-80.

40. O'Brien JT. Desmond P. Ames D et al. Temporal lobe magnetic resonance imaging can differentiate Alzheimer's disease from normal ageing, depression, vascular dementia and other causes of cognitive impairment. Psychol Med 1997; 27: 1267-75

41. Denihan A. Wilson G, Cunningham C et al. CT measurement of medial temporal lobe atrophy in Alzheimer's disease, vascular dementia, depression and paraphrenia. Int J Geriatr Psychiatry 2000; 15 306-12.

42. Olesen PJ, Gustafson DR, Simoni M et al. Temporal lobe atrophy and white matter lesions are related to major depression over 5 years in the elderly. Neuropsychopharmacology 2010; 35: 2638-45.

43. Øksengård AR, Haakonsen M, Dullerud R. Bildediagnostiske metoder ved demensutredning. Tidsskr Nor Lægeforen 2002; 122: 10-4.

Mottatt 15.3. 2013, første revisjon innsendt 12.9. 2013, godkjent 3.2. 2014. Redaktør: Tor Rosness. 